a simple but explicit form detailing strengths, weaknesses, and areas of need they have encountered during the semester.

Pre-and post-course testing, senior project testing, observations, and questionnaires should quickly alert instructors to what changes, additions, deletions, and adaptations are needed. An awareness of technological changes, before they occur, is built into the program. It is expected that any needed alteration can be addressed within a given semester or, at latest, by the following semester.

${ }^{1}$ Alvin Toffler, Powershift: Knowledge, Wealth, and Violence at the Edge of the 21st Century (New York: Bantam Books, 1990), 20.

${ }^{2}$ C.R. Finch and J.R. Crunkilton, Curriculum Development in Vocational and Technical Education, 3rd ed. (Boston: Allyn \& Bacon, 1989), 3-22.

\title{
Update: Information literacy
}

\author{
By Barbara J. Ford
}

ACRL's 52nd President

$\mathbf{K}$ nowledge is of two kinds: we know a subject ourselves, or we know where we can find information upon it."Dr. Samuel Johnson (1709-1784), Boswell's Life of Dr. Johnson.

Johnson's words from over 200 years ago are still pertinent today. The Commission on Higher Education recently concluded that information literacy is essential to assuring quality in the undergraduate library experience. I strongly support this conclusion and am pleased that ACRL has taken a leadership role in promoting information literacy. Throughout the year we have:

- published articles on information literacy in CéRL News;

- developed posters, pamphlets, folders, and even a frisbee that can be used to spread the word about information literacy in a variety of campus environments;

- presented programs on information literacy at ACRL chapter meetings;

- identified individuals who can serve as advisers to academic librarians working on information literacy;

- joined approximately 50 educational organizations affiliated with the National Forum on Information Literacy;

- planned a program including poster sessions for the ALA Annual Conference in Atlanta.

I want to thank all of you who responded to my request for assistance in defining information literacy. I enjoyed hearing about all of your innovative ideas and have found them useful.

I encourage each of you to review your library's programs to ensure that your patrons are getting the help they need to become information literate and to work with your faculty and administrators to promote the importance of information literacy. A brief list of resources immediately follows.

Note: A special note of thanks to my program planning committee who took a leadership role in many of the activities described here. Mary Reichel, chair; Patricia Senn Breivik; Lorene Brown; John Collins; Gemma Devinney; Joan Gotwals; Randy Hensley; Marilyn Lutzker; Ellen Meltzer; Barbara Moran; Sara Penhale; Billy Pennington; Brenda Purvis; Trish Ridgeway; and Ralph Russell.

\section{Information literacy resources:}

Rao Aluri and Mary Reichel, Information Literacy: Critical Skills for a Changing World. Chicago, ALA, 1990.

Lori Arp, "Information Literacy or Bibliographic Instruction: Semantics or Philosophy?" RQ 30 (Fall 1990): 46-49.

Patricia Senn Breivik, "Literacy in an Information Society." in The White House Conference on Library and Information Services, July 9-13, 1991, Discussion Papers. Washington, D.C.: The White House Conference on Library and Information Services, 1991.

Anita Kay Lowry, "Beyond BI: Information Literacy in the Electronic Age," Research Strategies 8 (Winter 19991): 22-27.

Hannelore Rader, Billie Reinhart, and Gary Thompson, Evaluating Information: A Basic Checklist. Chicago: ALA, 1990.

Trish Ridgeway, "Information Literacy: An Introductory Reading List," College \& Research Libraries News 51 (July/August 1990): 645-648. 